\section{Smith ScholarWorks}

\section{Comparison of Recent Coral Life and Death Assemblages to Pleistocene Reef Communities: Implications for Rapid Faunal Replacement on Recent Reefs}

\author{
Benjamin J. Greenstein \\ Cornell College \\ Lora A. Harris \\ Smith College \\ H. Allen Curran \\ Smith College, acurran@smith.edu
}

Follow this and additional works at: https://scholarworks.smith.edu/geo_facpubs

Part of the Geology Commons

\section{Recommended Citation}

Greenstein, Benjamin J.; Harris, Lora A.; and Curran, H. Allen, "Comparison of Recent Coral Life and Death Assemblages to Pleistocene Reef Communities: Implications for Rapid Faunal Replacement on Recent Reefs" (1998). Geosciences: Faculty Publications, Smith College, Northampton, MA.

https://scholarworks.smith.edu/geo_facpubs/52 


\title{
COMPARISON OF RECENT CORAL LIFE AND DEATH ASSEMBLAGES TO PLEISTOCENE REEF COMMUNITIES: IMPLICATIONS FOR RAPID FAUNAL REPLACEMENT ON RECENT REEFS
}

\author{
${ }^{1}$ Benjamin J. Greenstein, ${ }^{2}$ Lora A. Harris, and ${ }^{3} \mathrm{H}$. Allen Curran \\ ${ }^{2}$ Department of Geology, Cornell College, 600 First St. West, Mt. Vernon, Iowa 52314 \\ 2Department of Biological Sciences, Smith College, Northampton, MA 01063 \\ 'Department of Geology, Smith College, Northampton, MA 01063
}

\begin{abstract}
Marine ecologists and paleoecologists are increasingly recognizing that the Pleistocene and Holocene fossil record of coral reefs is the exclusive database from which an assessment of the long-term responses of reef communities to environmental perturbations may be obtained. The apparent persistence of coral communities in the face of intense fluctuations in sea level and sea surface temperature during glacial and interglacial stages of Pleistocene time is in marked contrast to dramatic fluctuations in reef commumity structure documented by short-term monitoring studies. We compared the taxonomic structure of live and dead coral communities on a modern patch reef currently undergoing a community transition to late Pleistocene facies exposed in the Cockbum Town fossil coral reef. Multidimensional scaling revealed that specific taxa and colony growth forms characterize life, death, and fossil assemblages. The recent decline of thickets of Acropora cervicornis is represented by their abundance in the death assemblage, while Porites porites dominates the coral life assemblage. Although additional study of Pleistocene reefal facies is required, the greater similarity of the death assemblage to the fossil assemblage suggests that the present Caribbean-wide decline of $A$. cervicornis is without a historical precedent.
\end{abstract}

\section{INTRODUCTION}

Community ecologists and paleoecologists are becoming increasingly aware that the fossil record is an exclusive and crucial database from which to interpret long term community patterns (Jackson 1992; Ricklefs and Schluter 1993; Jackson et al. 1996). During the last decade, paleoecological studies in terrestrial (e.g. Davis 1986; Delcourt and Delcourt 1991; Davis et al. 1994; Reed 1994; Coope 1995) and marine (e.g. Jackson 1992; Buzas and Culver 1994; Allmon et al. 1996; Jackson et al. 1996; Pandolfi 1996) systems have demonstrated that the fossil record possesses a wealth of information applicable to current concems for global environmental change as well as environmental perturbations on a local scale.

The Pleistocene fossil record of coral reefs over the last million years is a particularly valuable data repository because of its generally spectacular preservation, and because, with few exceptions, the same coral taxa that inhabit modern shallow water reef environments are present in Pleistocene deposits. Although this is in part due to the young geologic age of the interval, a great deal of qualitative (e.g. Mesollela 1967; Mesollela et al. 1970; White et al. 1984; White and Curran 1987; White 1989; Johnson et al. 1995; White and Curran 1995) and quanitative (Greenstein and Moffat 1996; Pandolfi 1996) data suggest spectacular preservation is common for reef coral assemblages accumulating during at least the last $600 \mathrm{ka}$ in both the Indo-Pacific and Caribbean provinces. The Caribbean shallow water coral (and mollusk) fauna has undergone little speciation or extinction since faunal turnover ended roughly a million years ago (Potts 1984; Allmon et al. 1993; Jackson et al. 1993; Budd et al. 1994; Jackson 1994a,b) in spite of intensifying cycles in climate and sea level throughout the Pleistocene.

With the above as an underlying assumption, Pleistocene fossil coral reef deposits can potentially be used as a database with which to address a variety of cardinal issues facing reef ecologists and marine resource managers, whose frustration over the temporally myopic view afforded by monitoring studies that rarely span a scientific career increasingly pervades the literature (e.g. Done 1992; Jackson 1992; Hughes 1994; Bak and Nieuwland 1995). Perhaps foremost among these issues, is an assessment of the response of coral reef communities to environmental perturbations. Important ecological influences on coral reefs may operate on a variety of temporal and spatial scales (Porter and Meier 1992), including decadal time scales (Bak and Nieuwland 1995; Done 1992), and the need for long term data sets has been recognized by a variety of workers (e.g. Likens 1987; D'Elia et al. 1991; Jackson 1992).

Jackson (1992) suggested that the fossil record represents the exclusive database from which responses of coral communities to global change may be gauged. For example, in Barbados, preliminary qualitative data from the Pleistocene raised reef terraces suggests that similar coral communities and zonation patterns have prevailed for the past $600 \mathrm{ka}$ (Jackson 1992). In an overview of mollusk, reef coral, and planktic foraminiferal communities, Jackson (1994a) found little correlation between the magnitude of environmental change and subsequent ecological and evolutionary response during Pleistocene time. In a very detailed study that examined geographic and temperal changes in community composition, Pandolfi (1996) found limited community membership in Indo-Pacific reef corals from $125-30 \mathrm{ka}$. These studies give a very different picture of coral reef community structure and stability than that derived from traditional, small-scale ecological studies in modern environments.

Given the utility of the Pleistocene fossil record of coral reef communities for assessing long-term responses to environmental perturbations, quantitative comparisons of these assemblages to modern reef communities is essential. Here, 
we compare the structure of communities of live and dead reef corals presently found on Telephone Pole Reef to that preserved in late Pleistocene age (Sangamonian) facies exposed near Cockburn Town to determine the accuracy with which the fossil record represents the taxonomic structure of a once-living coral community. Our results contrast with those obtained from similar companion studies, and suggest that the transition between coral communities currently occurring in Fernandez Bay (and indeed, throughout the Caribbean) may not have a historical precedent.

\section{STUDY SITES AND SAMPLING METHODS}

The regressive stratigraphic sequence exposed in the abandoned quarry in Cockburn Town, San Salvador, Bahamas, includes a coral rubblestone facies, composed predominantly of Acropora cervicornis, and a coral stone facies that contains abundant in situ Acropora palmata, Montastrea annularis and Diploria strigosa. These facies were defined by White et al. (1984) and Curran and White (1985) and suggested to represent back reef and reef tract environments, respectively. This fossil reef provides an excellent opportunity for a comparative taxonomic study because of its proximity to analogous modem reef environments (Fig. 1). Telephone Pole Reef, located in Fernandez Bay, is a mid-shelf patch reef that, in the past, was dominated by thickets of $A$. cervicornis set amidst larger heads of Montastrea annularis and other massive corals. Today, the degraded $A$. cervicornis thickets and rubble provide examples of the coral rubblestone facies described by White et al. (1984) and Curran and White (1985). The branching coral $A$. cervicornis has suffered a major decrease in abundance throughout the Caribbean region during the past two decades due to a combination of factors (see below). On Telephone Pole Reef, the once abundant stands of $A$. cervicornis have been significantly replaced by Porites porites (Curran et al. 1994).

\section{Field Methods}

We used the linear point intercept (LP) method (Lucas and Seber 1977) and constructed transects on Telephone Pole Reef and in the abandoned quarry area of the Cockbum Town fossil reef. In order to adequately estimate cover for the widest range of coral growth forms and colony sizes, transects were $40 \mathrm{~m}$ long (Mundy 1991), each separated by $20-50 \mathrm{~m}$. At $20 \mathrm{~cm}$ intervals along each transect, the transect intercept was observed. From the modern reef environments, the following data were recorded if the transect intercepted a coral: species, colony size, colony orientation, growth form, and whether the colony was alive or dead and whether whole or fragmented. Colonies that were partially dead and large enough to provide multiple intercepts were recorded as live or dead depending on what portion of the colony intercepted by the transect. The same data (with the obvious exception of whether the coral colony was alive or dead) were collected from transects laid across the Pleistocene reef facies exposed in the quarry.
Radiometric dates indicate that the Pleistocene reefs on San Salvador flourished between 119-131 ka (Chen et al. 1991).

In modern environments, we define the death assemblage as in situ dead coral material encountered along each transect (including dead portions of partially dead colonies) and coral rubble accumulating adjacent to the reef framework. Dead coral colonies encountered along the transect were identified to the species level only if we could recognize them without breaking them open or peeling off any algae or other overgrowth. Bulk rubble samples composed of dead coral were taken at the $5,15,25$, and $35 \mathrm{~m}$ marks of each transect. This methodology allowed us to adequately sample the death assemblage as defined above. Rubble samples were placed in a $5 \mathrm{~mm}$ mesh bag constrained by a $10 \mathrm{~L}$ bucket. Thus, coral species and growth form were recorded for each specimen $>5$ $\mathrm{mm}$ in size that preserved morphology sufficient to permit identification. Taxonomic data obtained from the rubble samples were pooled with those obtained from dead corals encountered along each transect.

\section{Data analyses}

We constructed species sampling curves to investigate whether our methodology adequately accommodated the diversity present in the coral assemblages studied. Comparison of taxonomic composition was calculated using the Bray-Curtis dissimilarity coefficient (Bray and Curtis 1957), which has been shown to be one of the most robust coefficients for the analysis of taxonomic composition data (Faith et al. 1987). Dissimilarity values range from 0 (for a pair of samples with identical taxonomic composition) to 1 (for a pair of samples with no taxa in common). Abundance data were transformed to their square roots prior to the analysis, to reduce the influence of occasional large abundance values for some taxa (Field et al. 1982). In addition, the transformed abundance values for each taxon were standardized by the maximum attained by that taxon. This standardization equalizes the potential contributions of taxa to the overall dissimilarity in composition. Without standardization by taxon, the Bray-Curtis values are dominated by those taxa that attain high abundances (Faith et al. 1987). The resulting Bray-Curtis matrix was subjected to an ordination technique that provided a visual summary of the pattem of dissimilarity values among the samples. The technique employed was global non-metric multidimensional scaling, or GNMDS (Kruskal 1964), which has been shown to be one of the most effective methods available for the ordination of taxonomic composition data (Minchin 1987). Each sample is represented as a point in a coordinate space with a given number of dimensions. The distances between each pair of points are, as far as possible, in rank order with the corresponding dissimilarities in taxonomic composition; points that are close together on the resulting scatter plot represent transects with similar coral constituents. The degree to which the distances on the scatter plot depart from a perfect rank order fit is measured by a quantity known as 


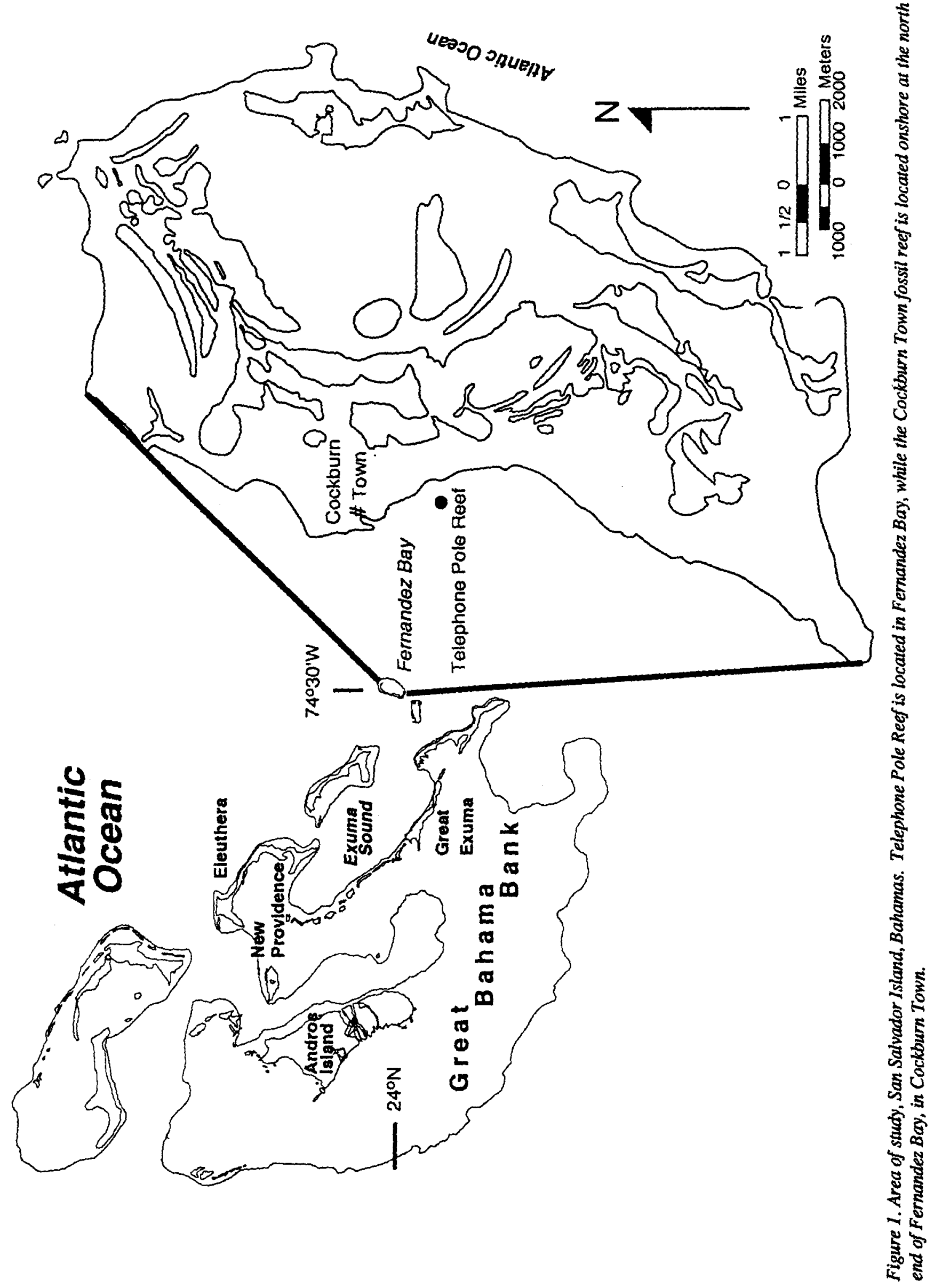


A. Life Assemblage
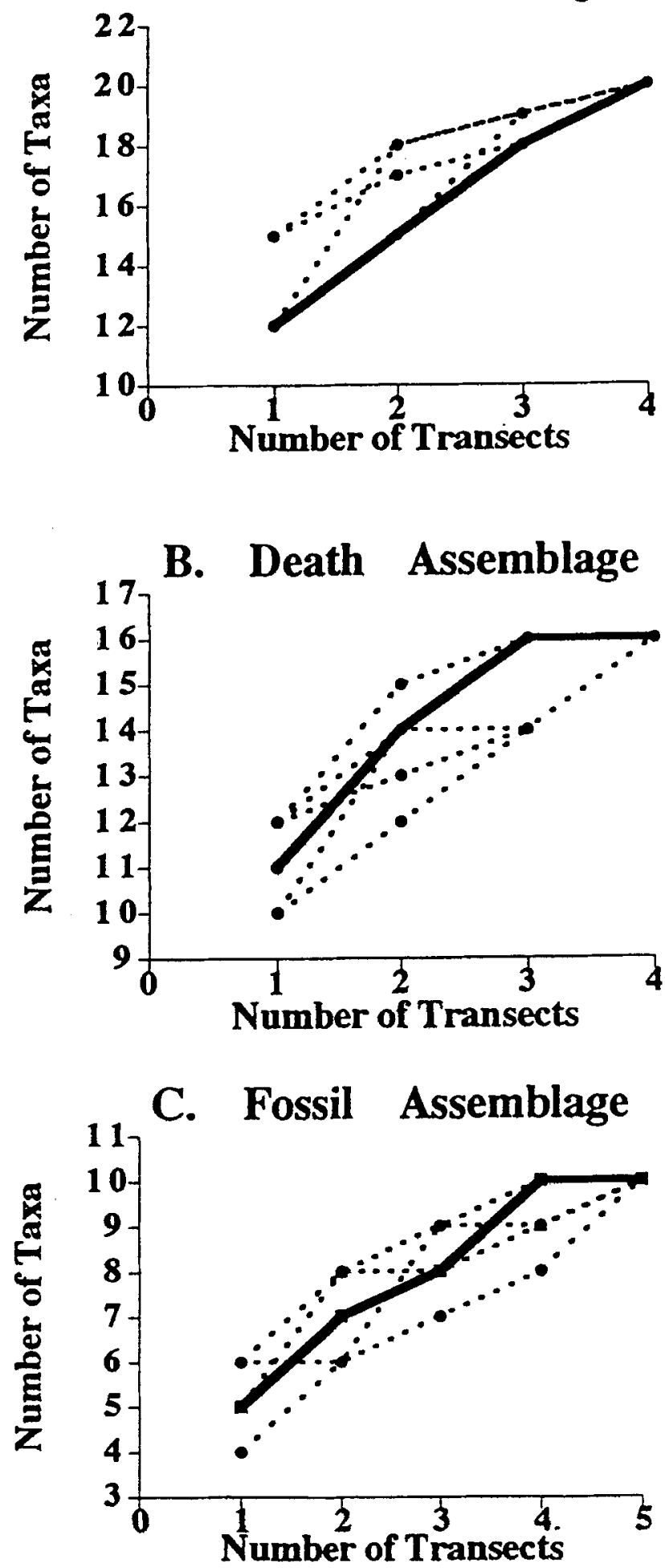

"stress". The lower the stress value, the better the representation of the samples in the multidimensional space [stress values less than 0.2 generally result in interpretable results (Clarke and Warwick 1994)]. The obtained stress values decreased minimally after a two dimensional analysis.

Species richness patterns were compared between life, death, and fossil assemblages. To compute species richness, the
-Figure 2. Cumulative diversity of reef coral species versus number of sampling intervals (transects) from live $(A)$, dead $(B)$, and fossil (C) reef coral assemblages present on San Salvador. Four transects accommodated the diversity present in both death and fossil assemblages, but were insufficient to account for the diversity present on the living reef. For all sampling curves, the solid line is a plot proceeding from the first transect through the last transect sampled for each assemblage; the dashed lines are plots of five random sequences of transects drawn from each assemblage.

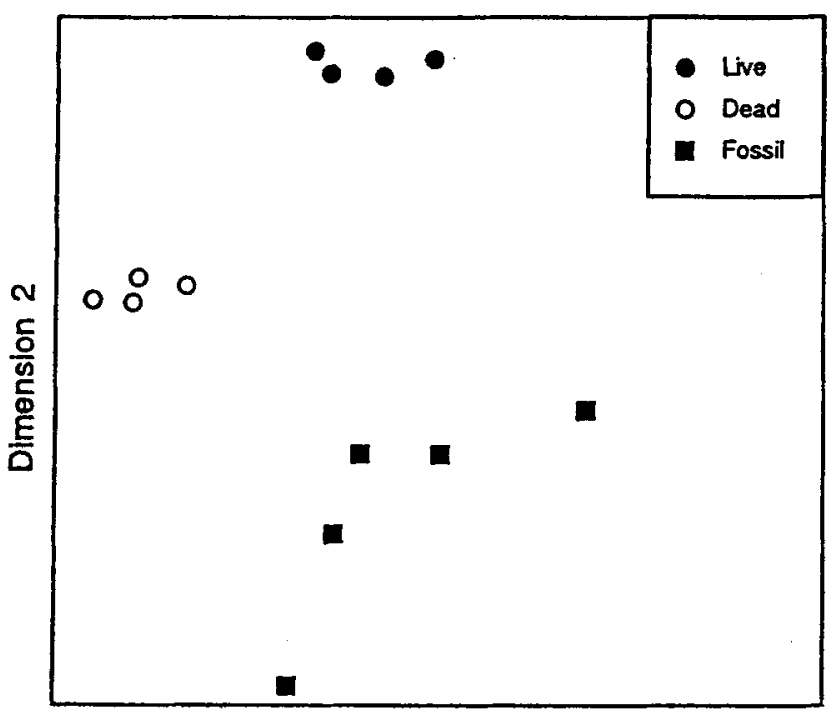

Dimension 1

Figure 3. Two dimensional global nonmetric multidimensional scaling (GNMDS) ordination of coral life death and fossil assemblages from San Salvador, Bahamas. Points closest to one another represent samples (transects) that are more similar in taxonomic composition than points farther away from one another. Note that each assemblage occupies a distinct portion of ordination space. The minimum stress value for the three dimensional analysis was 0.09 .

number of species in each sample was counted and then corrected for sample size. Thus, species richness $=(\mathrm{S}-1) /(\mathrm{log}$ $N$ ), where $S=$ the number of species present in a sample and $\mathrm{N}=$ total number of specimens counted.

\section{RESULTS AND DISCUSSION}

The limited size of the A. cervicornis-dominated thickets and rubble areas on Telephone Pole Reef allowed for construction of a total of four $40 \mathrm{~m}$ transects over modern life and death assemblages, while five transects were accommodated within the quarry area of the Cockbum Town fossil reef. The sampling curves indicate that four transects were insufficient to account for the full diversity of the life assemblage on Telephone Pole Reef (Fig. 2A). Sampling curves level off only between the final two transects for both the death and fossil assemblages (Figs. 2B and 2C); we hesitate to claim adequate sampling based on these results. 


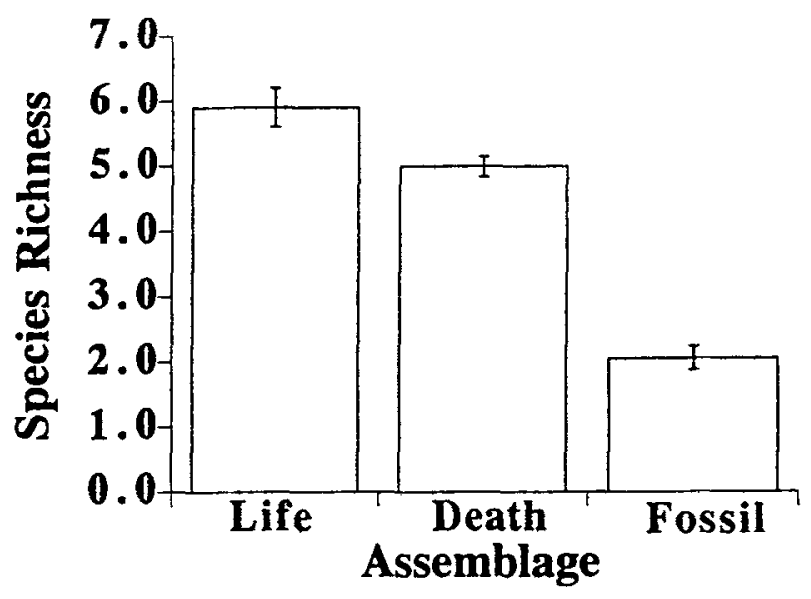

Figure 4. Comparison of coral diversity between life, death, and fossil assemblages on San Salvador as measured by Species Richness. Decreasing species richness values are the result of the lack of milleporids and taxa that are relatively rare on the living reef. Error bars are standard errors of the mean.

$\rightarrow$ Figure 5. Histogram of the frequency distribution of common coral taxa in life $(A)$, death $(B)$, and fossil $(C)$ assemblages preserved on San Salvador. Abundance data are transformed to square roots. Note the relatively high abundance of Porites porites, milleporids, and Montastrea annularis in the life assemblage. The death assemblage comprises Acropora cervicornis, A. palmata, and lower abundances of $\underline{M}$, annularis. For this histogram, data codes ( $x$-axis) are as follows: 1. Acropora palmata: 2. Porites astreoides; 3. Porites porites; 4. Agaricia agaricites; 5. Millepora sp.; 6. Diploria strigosa; 7. Favia fragum; 8. Millepora squarrosa; 9. Millepora complanata; 10. Millepora alcicornis; 11. Diploria clivosa; 12. Siderastrea radians; 13. Siderastrea siderea; 14. Acropora cervicornis; 15. Porites furcata; 16. Mycetophylia lamarckiana; 17. Montastrea cavernosa; 18. Mycetophylia danaana; 19. Copohyllia natans; 20. Dichocoenia stokesii; 21. Diploria labyrinthiformis; 22. Montastrea annularis; 23. Meandrina meandrites; 24. Solenastrea bournoni; 25. Solenastrea hyades.

Results of ordination reveal that samples from life, death, and fossil assemblages are clearly distinct from one another (Fig. 3). Moreover, the taxonomic composition of the death assemblage samples is more similar to samples from the fossil assemblages than samples from the life assemblages (Fig. 3). Analyses of species richness indicate that a significant decrease $\left(F_{(2,10)}=121.31 ; p<0.0005\right)$ in species diversity occurs from life to death to fossil assemblages (Fig. 4).

The discrimination between the life assemblage and the death and fossil assemblages by the ordination technique is interpreted to be the result of the recent change in coral
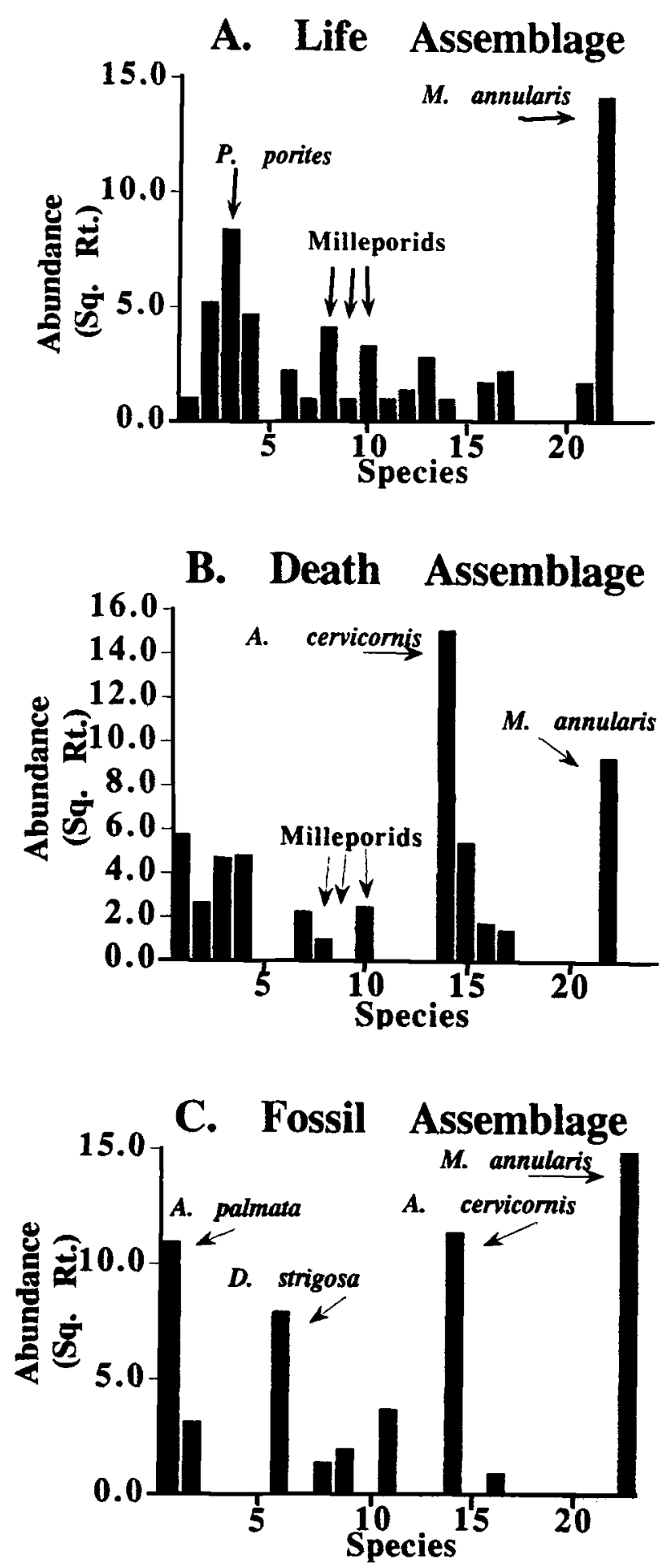

community structure on Telephone Pole Reef that is part of a Caribbean-wide phenomenon. Beginning at least as early as the 1980's, Acropora cervicornis has suffered an extreme decrease in abundance as a result of a confluence of factors including hurricanes (Woodley et al. 1981), spread of macroalgae consequent to sea urchin mass mortality (Lessios 1988), coral diseases and coral bleaching (Brown and Ogden 1993; Littler and Littler 1996; Miller 1996) and a variety of human-induced effects (Hughes 1994). On Telephone Pole reef, Acropora cervicornis has been replaced by large colonies 
of Porites porites. The previous A. cervicornis-dominated community is now manifested in the death assemblage (Fig. 5B), while $P$. porites is abundant only in the life assemblage (Fig. 5A). Additionally, the paucity of milleporids in either the death or fossil assemblage relative to the life assemblage further segregates life assemblage samples from those obtained from the fossil and death assemblages (compare Figs. 5A, 5B, and 5C). Susceptibility of those hydrozoans to the variety of physical, biological, and chemical processes that tend to destroy potential fossil material possibly implicates phylogenetic differences between hydrozoan skeletal microstructure and scleractinian skeletal microstructure as a source of difference in the preservation potential of these taxa. The decrease in species richness from live to dead to fossil assemblage results from the absence of the three milleporids we distinguished in our surveys (Millepora complanata, $M$. squarrosa and $M$. alcicornis) as well as taxa that are rare in the life assemblage (e.g. Diploria clivosa, Siderastrea radians, $S$. siderea, Montastrea cavernosa, Meandrina meandrites and Dendrogyra cylindrus, Fig. 5).

\section{Constancy and Change in Reef Community Structure}

The results we report here contrast with those obtained from companion studies comparing coral life and death assemblages occurring on modern Florida Keys reefs to Pleistocene reefs exposed in the Key Largo Limestone and on Great Inagua, Bahamas (Greenstein et al. in press and Greenstein and Curran 1997, respectively). In those studies, life assemblages currently thriving in the Florida Keys reef tract were demonstrated to be more similar to Pleistocene fossil assemblages than to their contemporary death assemblage. The striking difference obtained here is that the death and fossil assemblages are clearly most similar to each other in terms of the coral taxa they contain. There are three alternative hypotheses that explain the apparent failure of the Pleistocene assemblage exposed on San Salvador to accurately reflect the life assemblage currently in place offshore, while other Pleistocene strata we have studied apparently reflect modern reef coral life assemblages much more closely.

First, the demise of $A$. cervicornis in the Bahamas and Caribbean and subsequent replacement by another coral species (on Telephone Pole Reef, $P$. porites) is without historical precedent. In Belize, the once abundant stands of $A$. cervicornis have been replaced by Agaricia tenuifolia (Aronson and Precht 1997; Aronson and Plotnick, in press). Careful examination of cores taken through the reef sedimentary record in Belize revealed no recognizable signals (abrupt changes in coral taxa, or taphomonic evidence of an essentially monospecific death assemblage) of similar transitions, suggesting that the present drastic reduction of A.cervicornis has no precursor in the recent geological past (at least 3,800 years; Aronson and Precht 1997). In the Florida Keys, we (Greenstein et al., in press; Greenstein and Curran 1997) purposely chose modem reefs for our surveys that conformed to earlier (pre-1980) descriptions (for example
Multer 1977) of the majority of the reef tractreefs (for example abundant live Acropora palmata in the shallowest zones, grading to more diverse, deeper assemblages of living $A$. cervicornis, Porites astreoides, Montastrea annularis, and Diploria strigosa). It is compelling that these "healthy" reef communities were reflected by the fossil assemblages in the Florida Keys and Great Inagua, whereas the present Poritesdominated community on Telephone Pole Reef is not reflected by the fossil assemblage exposed on San Salvador. Moreover, it is sobering to consider the rapidity with which $A$. cervicornis-dominated communities have been altered. From this we can only conclude that, although the $A$. cervicornisdominated coral association persisted during Pleistocene climatic fluctuations, it is apparently vulnerable to the array of perturbations currently being inflicted on it.

A second hypothesis is that rapid changes in coral dominance within a community commonly occur, but the fossil record does not have sufficient resolution to preserve these temporally short-term fluctuations in reef community structure. Short-term studies of living coral reefs have recorded fluctuations of dominant species at virtually all spatial scales; ranging from meter quadrats (e.g. Hughes et al. 1987; Bak and Nieuwland 1995) through individual reefs (e.g. Porter et al. 1981; Woodley et al. 1981) to entire provinces (e.g. Lessios 1988). Moreover, short-term fluctuations may be a prerequisite for long-term stability (Chesson and Huntly 1989) and thus produce the type of longterm persistence of coral communities documented by Mesollela (1967), Jackson (1992), and Pandolfi (1996). We note here that several workers have outlined sedimentologic (e.g. White et al. 1984; White and Curran 1987; Curran et al. 1989; White 1989; White and Curran 1995) and taphonomic (e.g. Greenstein and Moffat 1996) evidence for rapid burial of late Pleistocene bank-barrier and lagoonal reef systems of the Bahama Archipelago during the post-Sangamonian regression. Thus live and dead corals were buried concurrently. Greenstein and Moffat (1996) demonstrated that specimens of A. cervicornis preserved in the quarry near Cockburn Town were actually less degraded than dead specimens accumulating on Telephone Pole Reef. In this case, the taphonomic evidence does not support a mass mortality event of this species during Sangamon time. In any event, it seems likely to us that rapid transitions similar to those observed presently in the Caribbean would be preserved somewhere had they occurred. The preliminary results reported by Aronson and Precht (1997) are encouraging in that they demonstrate that this hypothesis is eminently testable; and further microstratigraphic examination of Pleistocene coral-bearing strata should be undertaken. Foremost among these strata should be the units described here, as well as those from which long-term stability of Caribbean and Indo-Pacific reef coral communities has been reported (e.g. Mesollela 1967; Jackson 1992, 1994a; Pandolfi 1996).

A third alternative is that differences between the environmental setting of Telephone Pole Reef and that 
interpreted for the Cockburn Town fossil reef account for the differences we have obtained. White et al. (1984) and Curran and White (1985) interpreted the main portion of the Cockburn Town fossil reef as a reef tract system, whereas Telephone Pole Reef is a patch reef. Thus, the physical environment may not have permitted a take over by Porites porites or Agaracia tenuifolia (e.g. Aronson and Precht 1997). However, Greenstein and Moffat (1996) examined the mode of preservation of both Acropora palmata and $A$. cervicornis collected from the Cockburn Town fossil reef. Based on a variety of taphonomic criteria, they suggested that the fossil corals were derived primarily from a life assemblage that had been rapidly entombed. Had a die-off of $A$. cervicornis occurred during Sangamonian time, thickets of degraded $A$. cervicornis might potentially be preserved during such an event, and yield a much different taphonomic signal than that obtained by Greenstein and Moffat (1996). A twostep analysis of additional Pleistocene facies exposed in the Bahamas is needed to address this issue. First, to avoid circular reasoning, environmental interpretations of fossil reef assemblages should be made using criteria independent of coral content (for example constituent particle analyses coupled with detailed field descriptions [Pandolfi et al., in preparation]). Once a fossil assemblage has been determined to represent an environment like that currently hosting a reef undergoing transition in coral dominance, a comparative taxonomic study should be performed on both the modem and ancient assemblages.

\section{SUMMARY}

A comparison of the results of systematic censuses of live, dead, and fossil coral assemblages occurring in and adjacent to Fernandez Bay has yielded insight into the importance of the Pleistocene fossil record of coral reefs as an instrument with which to determine whether the presently observed changes in patch reef community structure in the Caribbean region have a historical precedent. We have determined that the rapid decline of Acropora cervicornis observed on a Bahamian patch reef (and observed around the Caribbean region) may be a unique perturbation that contrasts with the long-term persistence of this taxon during Pleistocene and Holocene time.

\section{CONCLUSIONS}

Although the results of our species sampling curves dictate that our results must be interpreted cautiously, primarily owing to relatively small sample size, we offer the following conclusions:

1. The fossil assemblage exposed in the Cockburn Town quarry is less species rich than its living and dead counterparts in Femandez Bay. This is the result of two factors: a) coral taxa that are rare in the life assemblage (e.g. Diploria clivosa, Dendrogyra cylindrus, Meandrina meandrites, and Montastrea cavernosa) are increasingly erased during the transition to the death and fossil assemblages; and b) the three species of hydrozoan common on the living reef are rare in the death and fossil assemblages.

2. Based on the assemblage of corals they contain, the death and fossil assemblages are more similar to one another than either is to the living coral assemblage. This result is in stark contrast to similar comparisons reported from the Florida Keys and Bahamas. We submit that this is the result of comparing a reef currently undergoing a transition to Porites porites-dominated coral assemblage from an Acropora cervicornis-dominated assemblage.

3. Further study of Pleistocene reef facies is needed to assess whether the current Caribbean-wide reduction in abundance of Acropora cervicornis has an historical precedent.

\section{ACKNOWLEDGMENTS}

Logistical support on San Salvador Island was provided by the Bahamian Field Station. Additional financial support to BJG and HAC from Smith College is gratefully acknowledged. John Pandolfi (Smithsonian Tropical Research Institute) provided the Bray-Curtis analysis. We acknowledge the Schultz-Sherman Fairchild Foundation for support to LAH. Kathryn Jermann, Sara Rosenzweig, and Sarah Smalheer (Smith College), served as field assistants. We thank Rich Aronson and an anonymous reviewer for constructive comments that significantly improved this manuscript.

\section{REFERENCES}

ALLMON, W.D., ROSENBURG, G., PORTELL, R.W., and SCHINDLER, K.S., 1993, Diversity of Atlantic coastal plain mollusks since the Pliocene: Science, v. 260, p. 1626-1629.

ALLMON, W.E., ROSENBURG, G., PORTELL, R.W., and SCHINDLER, K.S., 1996, Diversity of Pliocene-recent mollusks in the western Atlantic: extinction, origination, and environmental change, in Jackson, J.B.C., Budd, A.F., and Coates, A.G., eds., Evolution and environment in tropical America. University of Chicago Press, Chicago, p. 271-302.

ARONSON, R.B. and PLOTNICK, R.E., in press, Scaleindependent interpretations of macroevolutionary dynamics, in M.L. McKinney, ed., Biodiversity dynamics: tumover of populations, taxa, and communities. Columbia University Press, New York.

ARONSON, R.B. and PRECHT, W.B., 1997, Stasis, biological disturbance, and community structure of a Holocene coral reef: Paleobiology, v. 23, p. 326-346.

BAK, R.P.M. and NIEUWLAND, G., 1995, Long-term change in coral communities along depth gradients over leeward reefs in the Netherlands Antilles: Bulletin of Marine Science, v. 56, p. 609-619.

BRAY, J.R. and CURTIS, J.T., 1957, An ordination of the upland forest communities of southern Wisconsin: Ecological Monographs, v. 27, p. 325-349.

BROWN, B.E. and OGDEN, J.C., 1993, Coral bleaching: Scientific American, v. 268, p. 6470 .

BUDD, A.F., STEMANN, T.A., and JOHNSON, K.G., 1994, Stratigraphic distribution of genera and species of Neogene to 
recent Caribbean reef corals: Journal of Paleontology, v. 68, p. 951-977.

BUZAS, M.A. and CULVER, S.J., 1994, Species pool and dynamics of marine paleocommunities: Science, v. 264, p. 1439-1441.

CHEN, J.H., CURRAN, H.A., WHITE, B., and WASSERBURG, G.J., 1991, Precise chronology of the interglacial period: $\mathrm{Th}^{230} / \mathrm{U}^{234}$ data from fossil coral reefs in the Bahamas: Geological Society of America Bulletin v. 103, p. 82-97.

CHESSON, P. and HUNTLY, N., 1989, Short-term instabilities and long-term community dynamics: Trends in Ecology and Evolution, v. 4, p. $293-298$.

CLARKE, K.R. and WARWICK, R.M., 1994, Change in marine communities: an approach to statistical analysis and interpretation. National Environmental Research Council, United Kingdom, 144 p.

COOPE, G.R., 1995, Insect faunas in ice age environments, in Lawton, J.H. and May, RM., eds., Extinction rates. Oxford University Press, Oxford, p. 55-74.

CURRAN, H.A. and WHITE, B., 1985, The Cockburntown fossil coral reef, in Curran, H.A., ed. Pleistocene and Holocene carbonate environments on San Salvador Island, Bahamas Guidebook for Geological Society of America, Orlando annual meeting field trip, CCFL Bahamian Field Station, Ft. Lauderdale, Florida, p. 95-120.

CURRAN, H.A., WHITE, B., CHEN, J.H., and WASSERBURG, G.J., 1989, Comparative morphologic analysis and geochronology for the development and decline of two Pleistocene coral reefs, San Salvador and Great Inagua Islands, in Mylorie, J., ed., Proceedings, fourth symposium on the geology of the Bahamas. Bahamian Field Station, San Salvador, p. 107-117.

CURRAN, H.A, SMITH, D.P., MEIGS, L.C., PUFALL, A.E., and GREER, M.L., 1994, The health and short-term change of two coral patch reefs, Fernandez Bay, San Salvador Island, Bahamas, in Ginsburg, R.N., ed., Proceedings of the colloquium on global aspects of coral reefs: health, hazards, and history, 1993, Rosenstiel School of Marine and Atmospheric Science, University of Miami, Florida, p. 147. 153.

DAVIS, M.B., 1986, Climatic instability, time lags, and community disequilibrium, in Diamond, J. and Case, T.J., eds., Community ecology. Harper and Row, New York, p. 269-284.

DAVIS, M.B., SUGITA, S., CALCOTA, R.R., FERRARI, JB., and FRELICH, L.E., 1994. Historical development of alternate communities in a hemlock-hardwood forest in northem Michigan, USA, in Edwards, P.J., May, R.M., and Webb, N.R., eds., Large-scale ecology and conservation biology. Blackwell Scientific, Oxford, p. 19-39.

DELCOURT, H.R. and DELCOURT, P.A., 1991, Quatemary ecology: a paleoecological perspective. Chapman and Hall, London, $242 \mathrm{p}$.

D'ELIA, C.F., BUDDEMEIER, R.W., and SMITH, S.V., 1991 , Workshop on coral bleaching, coral reef ecosystems, and global climate change: report of proceedings. Maryland Sea Grant Publication, University of Maryland, College Park, Maryland, 91 p.

DONE, T.J., 1992, Constancy and change in some Great Barrier Reef coral communities: American Zoologist, v. 32, p. 655 . 662.

FAITH, D.P., MINCHIN, P.R., and BELBIN, L., 1987, Compositional dissimilarity as a robust measure of ecological distance: Vegetatio, v. 69, p. 57-68.

FIELD, J.G., CLARKE, K.R., and WARWICK, R.M., 1982, A practical strategy for analysing multispecies distribution patterns: Marine Ecological Progress Series, v. 8, p. 37-52.

GREENSTEIN, B.J. and MOFFAT, H.A., 1996, Comparative taphonomy of Holocene and Pleistocene corals, San Salvador, Bahamas: Palaios, v. 11, p. 57-63.

GREENSTEIN, B.J. and PANDOLFI, J.M., 1997, Preservation of community structure in modern reef coral life and death assemblages of the Florida Keys: implications for the Quaternary record of coral reefs: Bulletin of Marine Science, v. 19, p. 39-59.

GREENSTEIN, B.J. and CURRAN, H.A, 1997, How much ecological information is preserved in fossil reefs and how reliable is it? Proceedings of the 8th International Coral Reef Symposium, Panama City, Panama, v. 1, p. 417-422.

GREENSTEIN, B.J., PANDOL.FI, J.M., and CURRAN, H.A., in press, The completeness of the Pleistocene fossil record: implications for stratigraphic adequacy, in Donovan, S.K., ed. The adequacy of the fossil record. John Wiley and Sons, London.

HUGHES, T.P., REED, D.C., and BOYLE, M.J., 1987, Herbivory on coral reefs: community structure following mass mortalities of sea urchins: Journal of Experimental Marine Biology and Ecology, v. 113, p. 39-59.

HUGHES, T.P., 1994, Coral reef degradation: a long-term study of human and natural impacts, in Ginsburg, R.N., ed., Global aspects of coral reefs: health, hazards, and history, case histories. University of Miami, Rosenstiel School of Marine and Atmospheric Science, Miami, Florida, p. C20-C25.

HUGHES, T.P., 1994, Catastrophes, phase shifts, and large-scale degradation of a Caribbean coral reef: Science, v. 265, p. 1547-1551.

JACKSON, J.B.C., 1992, Pleistocene perspectives on coral reef community structure: American Zoologist, v. 32, p. 719-731.

JACKSON, J.B.C., 1994a, Constancy and change of life in the sea: Philosophical transactions of the Royal Society of London B, v. 344, p. 55-60.

JACKSON, J.B.C., 1994b, Community unity?: Science, v. 264, p. 1412-1413.

JACKSON, J.B.C., JUNG, C.P., COATES, A.G., and COLLINS, L.S., 1993, Diversity and extinction of tropical American mollusks and emergence of the Isthmus of Panama: Science, v. 260 , p. 1624-1626.

JACKSON, J.B.C., BUDD, A.F., and PANDOLFI, J.M., 1996, The shifting balance of natural communities? In D. Erwin, D. Jablonski, and J. Lipps, eds., Essays in Honour of James Valentine. University of Chicago Press, p. 89-122.

JOHNSON, K.G., BUDD, A.F., and STENMANN, T.A., 1995, Extinction selectivity and ecology of Neogene Caribbean reef corals: Paleobiology, v. 21, p. 52-73.

KRUSKAL, J.B., 1964, Multidimensional scaling by optimizing goodness of fit to a nonmetric hypothesis: Psychometrika, v. 29, p. 1-27.

LESSIOS, H.A., 1988, Mass mortality of Diadema antillarum in the Caribbean: What have we leamed?: Annual Reviews of Ecology and Systematics, v. 19, p. 371-393.

LIKENS, G.E., 1987, Long-term studies in ecology: approaches and alternatives. Springer-Verlag, New York, 214 p.

LITTLER, M.M. and LITTLER, D.S., 1996, Black band disease in the South Pacific: Coral Reefs, v. 15, p. 20.

LUCAS, H.A. and SEBER, G.A.F., 1977, Estimating coverage and particle density using the line intercept method: Biometrika, v. 64, p. 618-622.

MESOLLELA, K.J., 1967, Zonation of uplifted Pleistocene coral 
reefs on Barbados, West Indies: Science, v. 156, p. 638-640. MESOLLELA, K.J., SEALY, H.A., and MATTHEWS, R.K., 1970 , Facies geometries within Pleistocene reefs of Barbados, West Indies: American Association of Petroleum Geologists Bulletin, v. 54, p. 1899-1917.

MILLER, I., 1996, Black band disease on the Great Barrier Reef: Coral Reefs, v. 15, p. 58.

MINCHIN, P.R., 1987, An evaluation of relative robustness of techniques for ecological ordination: Vegetatio, v. 69, p. 89107.

MULTER, H.G., 1977, Field guide to some carbonate rock environments: Florida Keys and Western Bahamas. Kendall Hunt Publishing Co., Iowa, 415 p.

MUNDY, C., 1991, A critical evaluation of the line intercept transect methodology for surveying sessile coral reef benthos: Masters Thesis. University of Queensland, Australia, $126 \mathrm{p}$.

PANDOLFI, J.M., LLEWELLYN, G., and JACKSON, J.B.C., in preparation, Interpretation of ancient reef environments in paleoecological studies of community structure: Curacao, Netherlands Antilles, Caribbean Sea.

PANDOLFI, J.M. and GREENSTEIN, B.J., 1997, Preservation of community structure in death assemblages of deep water Caribbean reef corals: Limnology and Oceanography, v. 42, p. 27-38.

PANDOLFI, J.M., 1996, Limited membership in Pleistocene reef coral assemblages from the Huon Peninsula, Papua New Guinea: Constancy during global change: Paleobiology, v. 22, p. 152-176.

PORTER, J.W. and MEIER, O.W., 1992, Loss and change in Floridian reef corals: American Zoologist, v. 32, p. 625-640.

PORTER, J.W., WOODLEY, J.D., SMITH, G.J., NIEGEL, J.E., BATTEY, J.F., and DALLMEYER, D.G., 1981, Population trends among Jamaican reef corals: Nature, v. 294, p. 249 250.

POTTS, D.C., 1984, Generation times and the Quatemary evolution of reef-building corals: Paleobiology, v. 10, p. 46-58.
REED, K.E., 1994, Community organization through the PlioPleistocene: Journal of Vertebrate Paleontology, v. 14, p. 43A.

RICKLEFS, R.E. and SCHLUTER, D., eds., 1993, Species diversity in ecological communities: historical and geographical perspectives. University of Chicago Press, Chicago, 414 p.

WHITE, B., KURKJY, K.A., and CURRAN, H.A., 1984, A shallowing-upward sequence in Pleistocene coral reef and associated facies, San Salvador, Bahamas, in Teeter, J.W., ed., Proceedings of the Second Symposium on the Geology of the Bahamas, CCFL Bahamian Field Station, Ft. Lauderdale, Florida, p. 53-70.

WHTE, B. and CURRAN, H.A., 1987, Coral reef to eolianite transition in the Pleistocene rocks of Great Inagua, Bahamas. In Curran, H.A., ed., Proceedings of the third Symposium on the Geology of the Bahamas, CCFL Bahamian Field Station. Ft. Lauderdale, Florida, p. 165-179.

WHITE, B., 1989, Field guide to the Sue Point fossil coral reef, San Salvador Island, Bahamas, in Mylroie, J.E., ed., Proceedings of the Fourth Symposium on the Geology of the Bahamas, Bahamian Field Station, San Salvador, p. 353-365.

WHITE, B. and CURRAN, H.A., 1995, Entombment and preservation of Sangamonian coral reefs during glacioeustatic sea-level fall, Great Inagua Island, Bahamas, in Curran, H.A. and White, B., eds., Terrestrial and shallow marine geology of the Bahamas and Bermuda. Geological Sociery of America Special Paper 300, Boulder, Colorado, p. 51-61.

WOODLEY, J.D., CHORNESKY, E.A., CLIFFORD, P.A., JACKSON, J.B.C., HOFFMAN, L.S., KNOWLTON, N., LANG, J.C., PEARSON, M.P., PORTER, J.W., ROONEY, M.L., RYLAARSDAM, K.W., TUNNICLIFFE, B.J., WAHLE, C.M., WULFF, J.L., CURTIS, A.S.G., DALLMEYER, M.D., JUPP, B.P., KOEHL, A.R., NEIGEL, J., and SIDES, E.M., 1981, Hurricane Allen's impact on Jamaican coral reefs: Science, v. 214, p. 749-755. 